\title{
My Pocket Technology: Introducing a Mobile Assisted Inquiry Learning Environment (MAILE) to Promote Inquiries among Secondary Students
}

\author{
Sreelekha Leelamma ${ }^{1,2}$ \& Uma Devi Indira ${ }^{2}$ \\ ${ }^{1}$ Department of Atmospheric Sciences, University of Alabama, Huntsville, USA \\ ${ }^{2}$ NSS Training College Pandalam, University of Kerala, India \\ Correspondence: Sreelekha Leelamma, NSS Training College Pandalam, University of Kerala, India. E-mail: \\ lsreelekha8@gmail.com
}

Received: February 26, 2017

Accepted: March 12, 2017

Online Published: March 23, 2017

doi:10.5539/jel.v6n3p107

URL: http://doi.org/10.5539/jel.v6n3p107

\begin{abstract}
This paper introduces the Mobile Assisted Inquiry Learning Environment (MAILE), an Experimental Instructional Strategy (EIS) which employs an inquiry-based learning approach to guide secondary school students to learn environmental science in an engaging way supported by mobile phones. The students are situated in both the real world and the virtual world to extend their learning experiences. The effectiveness of this innovative approach is determined by comparing the learning effectiveness of an Experimental Group (EG) exposed to the experimental strategy and a Control Group (CG) taught the same content using the pedagogy prescribed by the state curriculum. The results show significant positive results in favor of the EG in multiple dimensions of cognitive learning prescribed by Bloom's Taxonomy: Knowledge, Comprehension and Application.
\end{abstract}

Keywords: inquiry-based learning, mobile learning, mosquito-borne diseases, cognitive learning achievements

\section{Introduction}

The mobile technology is opening vast educational access for the educators all over the globe. Its growth is phenomenal not only in the developed world but in the developing world as well. Mobile learning entails the kind of learning in which learners use mobile devices with digital content inside to learn in anytime, anywhere situations. Such devices include PDA, laptop computers, cellular phones with wireless communication capabilities, as well as customized hardware (Liu \& Hwang, 2010).

Mobile phones have become popular among the student community because of their cost-effectiveness, portability, and multiple operative capacity besides the social networking facilities they provide. In this study, we have addressed mobile phones as a "Pocket Technology" as it is with the students, anytime, every time and they are only too happy to pull it out to assist their classroom learning whenever the situation demands it. More than $50 \%$ of the student population has now access to mobile phones. The marriage of college students and cellphones is here to stay for both social and practical reasons (Nielsen, 2011).

Besides SMS text messaging which is very popular among the student community, mobile phones can help students to take down lecture notes, record lectures, demonstrations, schedule classroom activities, record peer seminars, debates, assignments, microteaching activities, and demonstration lessons. Mobile phones can be used during field trips to capture relevant data, which can be later put to a detailed analysis and discussion in the classroom. Thus, they offer students a remarkable opportunity to link the real world with the virtual world.

The primary interest of the study lies in understanding how mobile learning devices can promote inquiry-based pedagogies and how technology can be used to advance educational outcomes and student learning, particularly in the rural and under-resourced areas in the world. Few technological tools or applications have been designed to support inquiry-based pedagogies. This is an area in need for further research and Loi et al. (2010) argue for more academic studies to advance our "understanding of how students engage in inquiry-based learning in mobile learning environments". This need has to be more fulfilled in the developing world, as much of the research on technologically enhanced inquiry-based learning has been conducted in the developed world. 
The present study introduces a Mobile Assisted Inquiry Learning Environment (MAILE), wherein secondary students study an environmental science topic namely "mosquito-borne diseases" assisted by mobile phones. Students explore marshy areas around their school and neighborhood to observe, study, record and collect data to probe into the causes and consequences of a sudden spurt of mosquito borne diseases in their community. An attempt is also made to assess if there exists any connection between poor waste management practices of the public and rise in the incidence of mosquito borne diseases.

\section{Theoretical Framework and Related Literature}

\subsection{Inquiry Learning}

An important student centered strategy that is gaining prominence in the present educational scenario is Inquiry Learning. Inquiry based instruction is the creation of a classroom where students are engaged in essentially open ended, student centered hands on activities (Colburn, 2000). It requires deeper student involvement than learning for remembering select content of knowledge or simply answering questions or getting a correct answer. It espouses investigation, exploration, search, quest, research and pursuit (Kuhlthau, 2007). Inquiry learning is a more powerful form of learning as students have to engage multiple senses. It entails sharp observation skills, critical thinking needed to sift essential from non-essential data, compile and record facts systematically, discover relationships between variables and above all creativity in thinking to give a new interpretation to the discovered generalization.

There is a new emphasis on inquiry in the current National Science Education Standards. The standards specifically stress a reduction of learning facts in the content area of science and more emphasis on process, inquiry, deep understanding and communicating ideas. The organization states: "students understanding and abilities are grounded in the experiences of inquiry and inquiry is the foundation for scientific literacy". They recommend that teachers provide students with opportunities to "think and act in ways associated with Inquiry-asking questions, planning and conducting investigations, using appropriate tools and techniques to gather data, think critically and logically about relationships between evidence and explanations" (Kuhlthau, 2007). In 2008, Spronken and Rachel reported on the effectiveness of inquiry based learning in geography and its benefits for teachers and students. The study revealed that when students become active in the learning process, they evinced improved understanding, more enjoyable learning, developed valuable research skills, higher order learning outcomes and showed better academic performance.

Inquiry based learning encourages teachers to allow learners to get in touch with authentic situations, and to explore and solve problems that are analogous to real life (Feletti, 1993). Living in a democratic society it is important for the students to always understand their roles in the society. While investigating real world problems, students get motivated into the inquiry process of learning as compared to investigating some old concept in science. They are inspired to know what action could be appropriate and what would make a positive difference in improving the quality of life of themselves and their fellow beings.

This research aims to extend the experiences of inquiry learning to address real world problems connected with their immediate environment, namely the school and their neighborhood. The study is relevant in the context of rising evidences of mosquito borne diseases in India, especially in Kerala where diseases like chicken guinea and dengue were even unheard of about 10 years back.

However, inquiry involves the adoption of complex procedures and cannot be practiced by the average learner without the support of trained professionals and appropriate tools. To avoid students aimlessly wandering around, instructors need to carefully arrange the learning environments and design an interactive learning model along with meaningful learning content provided in time (Lim, 2004).

Several studies support this view. A study by Raes and Schellens (2012) revealed that multiple scaffolding enhances both knowledge acquisition and metacognitive awareness among students learning science through web based collaborative inquiry learning. The finding by Roll and Holmes (2012) suggest that process-guidance in the form of metacognitive scaffolding augmented the inherent benefits of invention activities of learners as compared to learners without any guidance. In 2006, Sharpe examined the different dimensions of scaffolding for on-line historical inquiry. Written prompts and argumentation formed the fixed scaffolds while adaptive scaffolds include questioning, modeling and peer interactions. The above studies clearly suggest that students gain competence in their inquiry learning when they receive proper scaffolding.

\subsection{Mobile Learning}

Mobile phones are found to be very effective in building learning environments, extending learning experiences outside the classroom and in kindling the ingenuity, critical thinking and problem solving abilities in children. 
The major affordances of mobile learning technologies for learning include mobility resulting from device portability, relatively strong computing power in small devices and always on connectivity (Hsu \& Ching, 2013). Mobile devices such as smart phones or iPod touches are vastly gaining popularity due to the availability of easy to use mobile software applications (Johnson, Levine, Smith, \& Stone, 2010).

Seol, Sharp and Kim (2012) introduced The Stanford Mobile Inquiry-based Learning Environment wherein students used mobile phones to create questions in an engaging way and share them with peers in an elementary classroom. The results showed that the students were very satisfied with the activity. Hsu, Chang (2013) studied the educational value of mobile app design activities and the web based visual programming tool, and the possibility of teaching/learning mobile app design online. Meanwhile Shih, Chuang, Hwang (2010) examined how inquiry based mobile approach can be used to enhance learning effectiveness in social science by taking cognitive load into consideration.

The purpose of the study was to create awareness among parents, teachers and school authorities at large about the immense educational opportunities offered by mobile phones. In schools across India, mobile phones are a taboo, viewed as an instrument that destroys the character, morale and value system of the learners. In this context, the investigator observed that students are very eager to know, familiarize and use the new technology. It is their ignorance about its educational potentialities that prompts children to use them for recreational purposes alone. In a recent study, it has been evidenced that the game Pokémon has been downloaded 500 million times. This points to the popularity of this device among children. A powerful pedagogical tool is being underutilized (Seol, Sharp, \& Kim, 2012). Students are actively trying to communicate with each other during class on their mobile phones. So, there is an opportunity to redirect this communication towards class material through student created questions. Indeed, it is slowly being recognized and demonstrated that mobile phones are highly engaging tools to be taken advantage of and not to be prohibited (Kolb, 2008).

In this study, mobile phones helped students to record information and share them with their peers. Students made use of the camera and video functions to record the different stages of the life cycle of mosquitoes they observed in the marshy areas around their schools and neighborhood. This helped them to later identify the different species of the mosquitoes observed and the diseases they spread. When additional information was needed, they also made use of the internet facility and Google available in the mobile phones of a few students. The information, thus collected was shared among the different group members. This helped to create a collaborative learning atmosphere. Students also used the mobile phones to text inquiry questions.

The researcher and the trainees scaffolded the inquiry process by giving them necessary hints, cues and prompts. To give proper direction to the inquiry procedure of the students, the researcher also posted questions prompting inquisitiveness, through their mobile phones. In inquiry-oriented field trips of this kind, dialogue is a key resource for scaffolding student's cognitive growth. The teachers provided verbal scaffolds- (questions, cues, prompts, supports, coaching, modelling) that enabled students to build powerful thinking strategies and conceptual understanding. The teacher's questions such as "What are the connections between what you observed and what you already know? Motivated the learner and put him in the track of true inquiry.

\section{Research Methods}

\subsection{Purpose}

The objective was to test the cognitive learning achievements of a group of secondary school students (EG) in learning select topics of environmental science when employing the Mobile Assisted Inquiry Learning Environment (MAILE) as compared to another group (CG) taught the same content using the activity method of instruction followed in the schools of Kerala.

\subsection{Research Design}

The investigator adopted the "quasi-experimental" design, "the pre-test post-test non-equivalent group experimental design" with appropriate adjustments for the present study. This meant the comparison of an Experimental Group (EG) with a Control Group (CG) for their learning of a standard content, making use of the experimental instructional strategy for the EG and the conventional classroom teaching for the CG.

The study was conducted in Kerala, India. Three districts namely Kollam, Pathanamthitta, and Alappuzha were selected for the study. Alappuzha has special importance because it is the land of backwaters, lagoons and lakes and hence the largest incidences of mosquito borne diseases are reported from this district. Besides the researcher, four teacher trainees were assigned to each school. This helped the researcher to coordinate the work more effectively. The study was conducted during the monsoon season (June, July) which is the breeding season of mosquitoes 


\subsection{Study Group}

An experimental sample was worked out based on interest, willingness and ability of students to participate in the proposed study in consultation with the principal and concerned teachers. In each school, two groups were identified, an experimental group and a control group, by random pairing based on class test scores in science by the concerned teachers. The same procedure was repeated in all the three schools. The combined numbers available for final statistical analysis were 68 students for EG and 66 students for CG.

\subsection{Instructional Design}

The EG and CG were exposed to two instructional strategies respectively. Before the conduct of the experiment, the two groups were administered a pre-test to assess their entering behavior in the topic namely "mosquito-borne-diseases in Kerala". After the experimental treatment, both the groups viz., the EG and the CG received a post-test consisting of test items, giving equal weight age to all the three components of cognitive learning achievements used in the study - Knowledge, Comprehension and Application.

\subsubsection{Design for the Experimental Group (EG)}

Three learning stages were designed to guide the EG students through the inquiry process supported by mobile phones.

\section{1) Learning stage 1}

Students of the EG were given an orientation to inquiry learning, steps and procedure to be followed, instructions on how to use the mobile phones to take videos and photos of the different stages of mosquitoes' life cycle and how to create and share inquiry questions with peers and teachers. Students were divided into groups of five. Students who owned a mobile phone were allowed to use them with the permission of their parents. Most students used their own cell phones. At least two mobile phones were required for each group. However, the investigator provided four mobile phones in all to those groups where there were only one.

They visited marshy areas around their school and neighborhood, collected samples of water from these marshy areas in large trays and observed the growth cycle of the mosquito larvae contained in them. Each group also had to identify the species of the mosquitoes under observation, which they did with the help of their science teacher using microscopes available in their science laboratory. The data gathered were neatly entered in their science notebooks. Students also made use of the internet facility available in their phones to identify the diseases spread by each species of the mosquitoes they observed. This study mainly made use of the camera and video functions of mobile phones. Besides Google, a few students were familiar with the application Jott, a free web resource that enables a user to create mobile notes. Jott allows a user to create speech to text e-mails from a cell phone. The students were also given an orientation on cell phone etiquette inside and outside of school. This helped them to understand what is appropriate and what is not appropriate while using cell phones both as a learning device and a social tool.

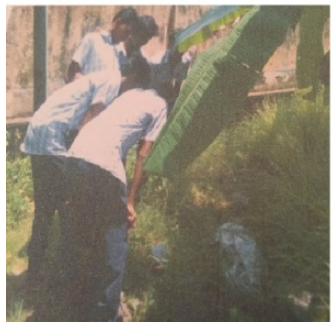

a). Field Observation

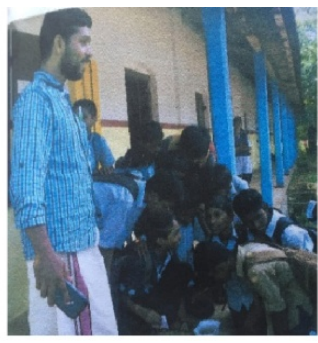

b) Sample Study

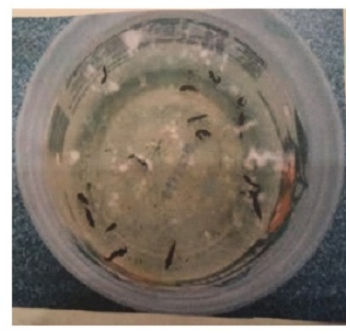

c) Images of Mosquito Larva

Figure 1. Field observation and sample study 


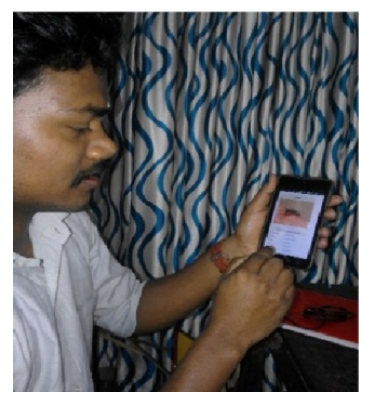

a) Preparing Digital Inquiry Questions using Google

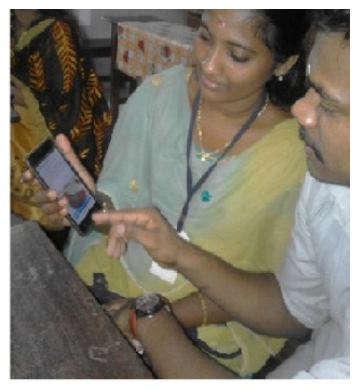

b) Sharing with Peers

Figure 2. Student activity supported by MAILE

\section{2) Learning stage 2}

Each group of students was required to synthesize and categorize the data collected. They prepared a detailed written report on the different stages of inquiry conducted and their findings. This helped to clarify facts and stimulate higher levels of thinking and make learning permanent among group members.

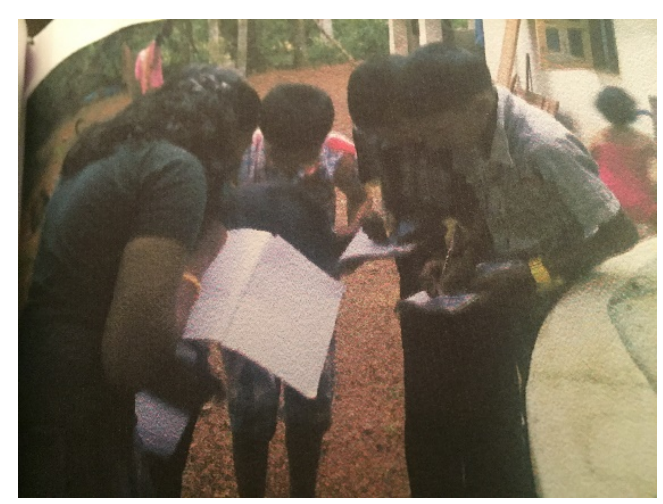

Figure 3. Entering observations in science notebooks

\section{3) Learning Stage 3}

At this stage, each group shared their findings with other group members through a PowerPoint presentation of 8-minute duration. They were also required to chalk out a plan of action outlining what measures they would adopt to control the spread of these dangerous insects and the diseases they spread.
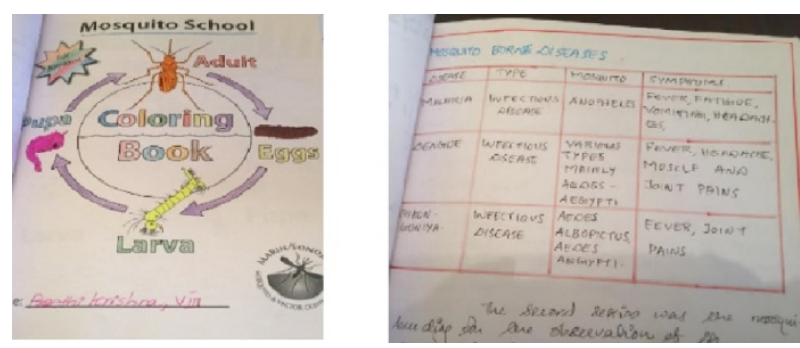

Figure 4. MAILE learning products created by students 

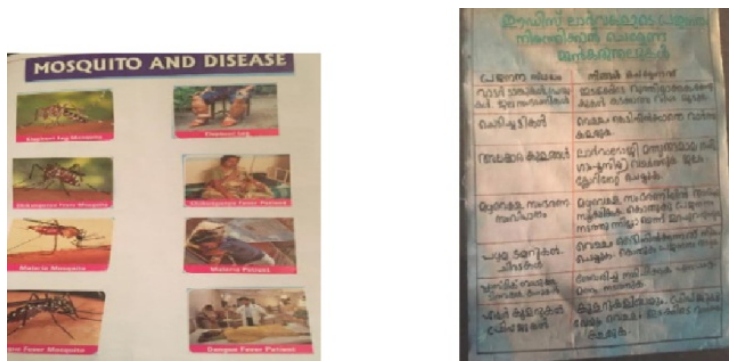

Figure 5. Student presentations to create public awareness

\subsubsection{Design for the Control Group-CG}

Lesson designs were prepared strictly adhering to the "Activity-based critical pedagogy" prescribed for teaching in the state schools of Kerala. Six lesson designs were prepared to cover the topic. Science Text books were supplemented by collaborative group discussions to teach the prescribed topic.

\section{Results}

The study seeks to find out the efficacy of the Experimental Instructional Strategy (EIS) namely "MAILE" in exhibiting multiple dimensions of learning namely, Knowledge, Comprehension and Application as defined in the Bloom's Taxonomy of Educational Objectives compared to the practicing methodology followed in the secondary schools of Kerala.

Table 1. Comparison of the performance of the EG and CG for the "knowledge component"

\begin{tabular}{ccc}
\hline & Experimental Group & Control Group \\
\hline Mean & $7.9\left(\mathrm{M}_{1}\right)$ & $5.3\left(\mathrm{M}_{2}\right)$ \\
Standard Deviation & 0.3 & 1.2 \\
Sample size & $68\left(\mathrm{~N}_{1}\right)$ & $66\left(\mathrm{~N}_{2}\right)$ \\
\hline
\end{tabular}

The statistical test of significance for difference between the means of the EG and CG has yielded a t-value of 17.15, which is far greater than the critical level set for difference at the 0.01 level, viz., 2.58. This leads to the conclusion that the EIS had a greater influence in developing the "knowledge component" of the EG as against the $\mathrm{CG}$, who were taught using the practicing school pedagogy of teaching.

Table 2. Comparison of the performance of the EG and CG for the "comprehension component"

\begin{tabular}{ccc}
\hline & Experimental Group & Control Group \\
\hline Mean & $6.9\left(\mathrm{M}_{1}\right)$ & $3.2\left(\mathrm{M}_{2}\right)$ \\
Standard Deviation & 0.1 & 1.1 \\
Sample size & $68\left(\mathrm{~N}_{1}\right)$ & $66\left(\mathrm{~N}_{2}\right)$ \\
\hline
\end{tabular}

Critical Ratio $=20.93(t)$

The statistical test (Two-tailed test of significance for difference between means of large independent samples) has yielded a considerably high $\mathrm{t}$-value $(\mathrm{t}=20.93)$. The critical limit for significance at the 0.01 level is 2.58 . The t-value obtained in the present comparison is very much higher than the above critical limit. This leads to the conclusion that the instructional strategy was very effective in developing the "comprehension component" of the EG in the selected topic when compared to the CG. 
Table 3. Comparison of the performance of the EG and CG for the "application component"

\begin{tabular}{ccc}
\hline & Experimental Group & Control Group \\
\hline Mean & $3.6\left(\mathrm{M}_{1}\right)$ & $1.5\left(\mathrm{M}_{2}\right)$ \\
Standard Deviation & 0.5 & 0.7 \\
Sample size & $68\left(\mathrm{~N}_{1}\right)$ & $66\left(\mathrm{~N}_{2}\right)$ \\
\hline
\end{tabular}

The statistical test of significance for difference between means of EG and CG has given a t-value of 20.93 which is far higher than the critical level set for difference at the 0.01 level. This leads to the conclusion that the experimental strategy was very effective in developing the "application component" of the EG in the selected topic when compared to the CG.

\section{t- values of Knowledge, Comprehension \& Application}

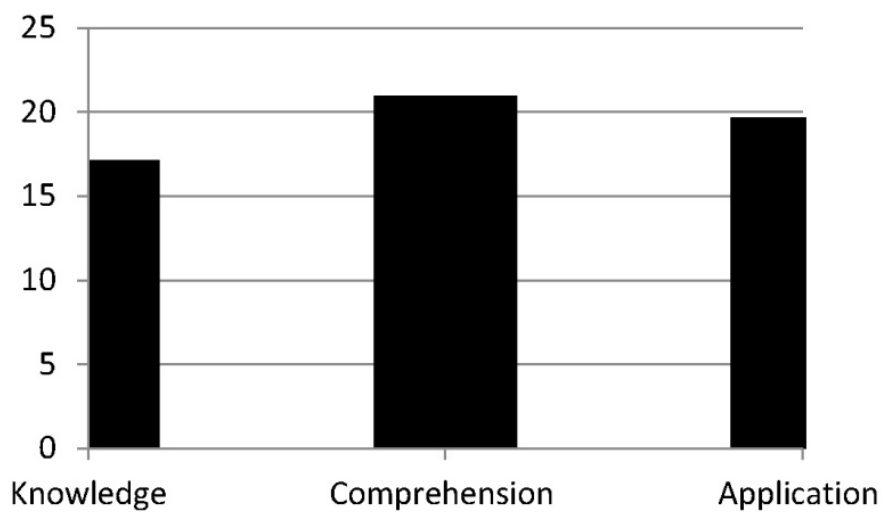

Figure 6. t-values

\subsection{Student Evaluation of MAILE}

Students were required to evaluate their preference for MAILE as an innovative and engaging method of science learning as compared to the practicing Activity-based classroom Pedagogy, by expressing their preferences in a survey which included closed ended Likert-Type question. Students evaluated their preference for MAILE on a four-point Likert-scale from (Very satisfied to Not satisfied). 


\section{Students Evaluation}

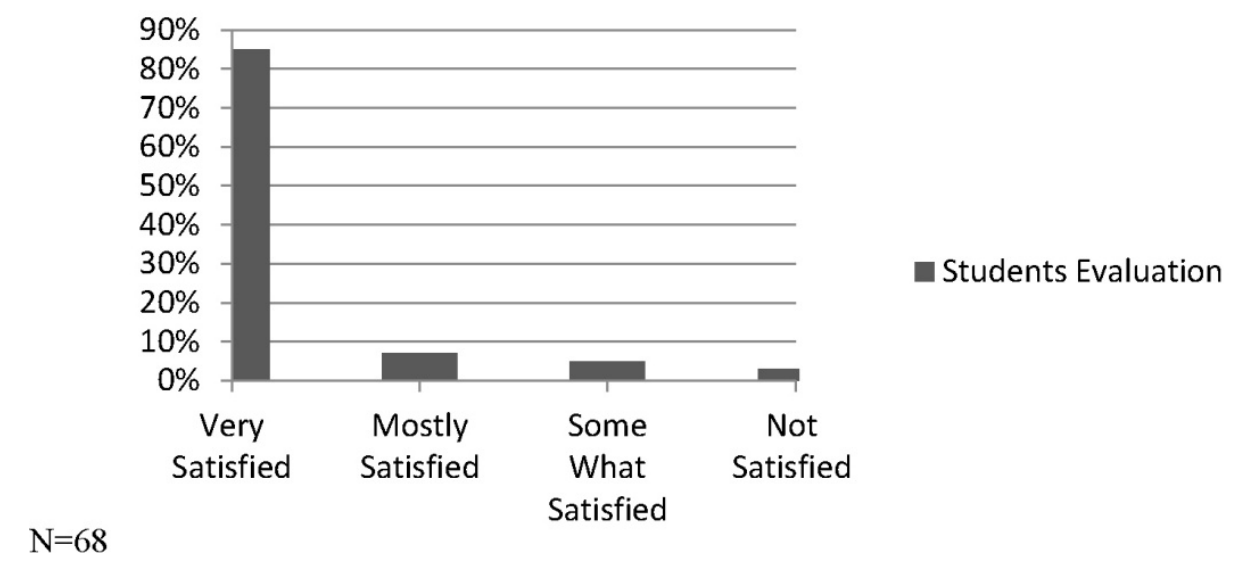

Figure 7. Student evaluation of MAILE

\section{Discussion of Findings}

Results of the analysis clearly show that high t-values were obtained for all the three components of learning effectiveness - namely knowledge, comprehension and application. This is a clear proof that the EIS namely Mobile Assisted Inquiry Learning Environment (MAILE) is very effective when compared to the practicing teaching methodology followed in the schools of Kerala. The comparison of the t-values shows that EIS has a special advantage in developing the Comprehension component ( $t$-value 20.93) when compared to the other two components namely Knowledge (t-value 17.15) and Application (t-value 19.66). The t-values also points to the fact that the EIS is more effective in developing the application component when compared to knowledge.

The special advantage towards comprehension component of learning effectiveness of the EG could be because students had a chance to gain an in-depth understanding of the learning content by physically observing the life cycle of the mosquitoes and this experience strengthened their understanding and application capabilities with respect to the learning of the content when compared to their counterparts in the CG who studied the content based on the text book facts. The students in the EG not only performed their individual observations but also shared their findings and discussed their observations with the peers in the group. Moreover, they also made use of their mobile pictures and videos in the process of learning which helped to concretize the concepts involved. This helped to strengthen their application skills.

As shown in the Figure 7 above, students were asked to evaluate their preference for MAILE as an innovative experimental pedagogy. The results show that $85 \%$ of respondents (58) were very satisfied with MAILE, while $7 \%$ (5) mostly agreed, $5 \%$ (3) slightly agreed and 3\% (2) strongly disagreed. A personal interview was conducted with the two students who strongly disagreed to this new method. One student opined that "I find inquiry very boring and tiring". The other student's view was "I am not comfortable with mobile phones and I do not like wandering outside. I understand better when my teacher teaches me using the blackboard".

Another interesting observation was that the EIS namely "MAILE" was found to be very effective for the slow learners as they could learn by seeing, doing and interacting with their physical environment instead of listening to teachers and memorizing facts from their text books. As for the gifted students, the inquiry learning provided by MAILE helped them to engage their curiosity, to go beyond just fact finding to synthesize and assimilate facts, to construct new ideas and develop deep understanding. For the students, it was their first learning experience both in terms of inquiry learning and using mobile phones. The field work thrilled them and all the students of the EG participated wholeheartedly. It came as a surprise for them, to see mobile phones (which was until then a taboo in the school compound) being distributed among their peers with the consent of their teachers. This experience served as an eye-opener to both the students and their teachers regarding the immense educational opportunities offered by the mobile phones. 


\section{Conclusion and Future Research}

This research emphasizes the effectiveness of an experimental instructional strategy namely Mobile Assisted Inquiry Learning Environment (MAILE). We have addressed it as a "Pocket Technology" as it is with the students, anytime, every time and they are only too happy to pull it out to assist their classroom learning whenever the situation demands it. Our primary interest lies in understanding how mobile phones can promote inquiry-based pedagogies and how technology can be used to advance educational outcomes and student learning.

The results show that the students' cognitive learning achievements made significant improvements in all the three-multiple dimensions of learning-Knowledge, Comprehension and Application. However, MAILE was found to be most effective in promoting comprehension capabilities among students when compared to the other two. Again, MAILE is more effective in promoting application component of student learning when compared to that of knowledge. This is a clear indication that the EIS is more effective in promoting higher order learning objectives. To establish this, more research is needed to find out the effectiveness of MAILE on higher learning outcomes such as Analysis, Synthesis and Evaluation and on Total Cognitive Outcomes. Student evaluation of MAILE also clearly indicates that $85 \%$ of the students were very satisfied with MAILE.

This study was confined to only three districts of Kerala. Moreover, only public schools belonging to the rural and sub-urban areas were included. One science topic "Mosquito-borne diseases of Kerala" and only three objectives of the cognitive domain of Bloom's Taxonomy were considered. More research is needed to find out the effectiveness of MAILE on higher order cognitive outcomes. A comparative study of the mean total cognitive terminal behavior scores of the experimental group and control group and mean cognitive terminal behavior of the sub-components of each of the two groups, and intercorrelations among the different objectives are areas that needs further research.

\section{Implications}

Based on the findings of this research, educators need to reconsider how learning situations can be made more interesting and engaging by introducing field work and new generation tools like mobile phones, how teachers can take advantage of student curiosity and prepare them to be creative thinkers and active problem solvers. An interesting behavioral change that was observed in the students is that they became aware of the seriousness of the diseases spread by mosquitoes, what preventive measures need to be taken, and vowed to take this understanding back to their neighborhood and do all what they could to keep their surroundings clean. All the students collectively expressed the dire need for a community awareness program to educate the public on how the unhealthy habit of dumping household and commercial wastes in waterbodies, open areas and marshy lands was threatening the life of themselves and their children.

Confident with the success of MAILE, we are planning to extend it to other lessons, subjects and disciplines. Hopefully we may be able to extend it to other districts, states and even nation-wide.

\section{Acknowledgements}

This research was supported by the UGC (India) Raman Fellowship for Post-Doctoral Research in U.S.A. We would like to thank all the students, teachers and teacher-trainees who helped us in this study.

\section{Reference}

Bloom, B. S. (1956). Taxonomy of educational objectives, Handbook 1: Cognitive domain. New York: David McKay.

Brookhart, S., Moss, C., \& Long, B. (2008). Formative assessment that empowers. Association for Supervision \& Curriculum Development, 66(3), 52-57.

Cheung, S. L. (2008). Using mobile phone messaging as a response medium in classroom experiments. The Journal of Economic Education, 39(1), 51-67. https://doi.org/10.3200/JECE.39.1.51-67

Colburn, A. (2000). An inquiry primer. Science Scope, 23(6), 42-44.

Denny, P., Luxton-Reilly, A., \& Simon, B. (2009). Quality of student contributed questions using peer wise. Proc. $11^{\text {th }}$ Australasian Computing Education Conference, 95, 55-63.

Dori, Y. J., \& Herscovitz, O. (1999). Question-posing capability as an alternative evaluation method: Analysis of an environment case study. Journal of Research in Science Teaching, 36, 411-430. https://doi.org/10.1002/(SICI)1098-2736(199904)36:4\%3C411::AID-TEA2\%3E3.0.CO;2-E 
Feletti, G. (1993). Inquiry based and problem based learning: How similar are these approaches to nursing and medical education? Higher Education Research Development, 12(2), 143-156. https://doi.org/10.1080/0729436930120203

Gall, M. D. (170). The use of question in teaching. Review of Educational Research, 40, 707-721. https://doi.org/10.3102/00346543040005707

Gilroy. (2004). Invasion of the classroom cell phones. The Hispanic Outlook in Higher Education, 56-60.

Hsu, Y.-C., \& Ching, Y.-H. (2013). Mobile APP design for teaching and learning. educator's experience in an online graduate course. Open Journal System, International Review of Research in Open and Distributed Learning (IRRODL), 14(4). https://doi.org/10.19173/irrodl.v14i4.1542

Johnson, L., Adams., \& Cummins, M. (2012). Mobile Apps. The NMC Horizon Report, 2012 higher education edition. Austin, Texas: The New Media Consortium.

Johnson, L., Leviene, A., Smith, R., \& Stone, S. (2010). The 2010 Horizon Report. Austin, Texas: The New Media Consortium.

Kolb, L. (2008). Toys to tools: Connecting student cell phones to education. Washington: International Society for Technology in Education.

Kuhlthau, C., Maniotes, L. K., \& Caspari, A. K. (2007). Guided inquiry: Learning in the $21^{\text {st }}$ century. West Port: Libraries Unlimited.

Lee, H. S., Liu, O. L., \& Linn, M. C. (2011). Validating measurement of knowledge integration in science using multiple-choice and explanation items. Applied Measurement in Education, 24(2), 115-136. https://doi.org/10.1080/08957347.2011.554604

Li, D. D., \& Lim, C. P. (2008). Scaffolding online historical inquiry tasks: A case study of two secondary level school classroom. Computers and Education, 30(1), 1394-1410. https://doi.org/10.1016/j.compedu.2006.12.013

Lim, B. R. (2004). Challenges and issues in designing inquiry on the web. British Journal of Education Technology, 35(5), 627-643. https://doi.org/10.1111/j.0007-1013.2004.00419.x

Liu, G. Z., \& Hwang, G. J. (2010). A key to understanding paradigms shifts in e-leadership: Towards context aware ubiquitous learning. British Journal of Educational Technology, 41(2), e1-e9. https://doi.org/10.1111/j.1467-8535.2009.00976.x

Looi, C. K., Seow, B. H., Zhang, C., \& Wong, L. H. (2010). Leveraging mobile technology for sustainable seamless learning: A research agenda. British Journal of Educational Technology, 41(2), 154-169. https://doi.org/10.1111/j.1467-8535.2008.00912.x

Marbach-Ad, G., \& Sokolove, P. G. (2000). Can undergraduate biology students learn to ask higher level questions? Journal of Research in Science Teaching, 37(8), 854-870. https://doi.org/10.1002/1098-2736(200010)37:8\%3C854::AID-TEA6\%3E3.0.CO;2-5

Mayer, R. E. (1997). Multimedia learning: Are we asking the right questions? Educational Psychologist, 32(1), 1-19. https://doi.org/10.1207/s15326985ep3201_1

Mayer, R. E. (2005). Cognitive theory of multimedia learning. In The Cambridge handbook of multimedia learning. Cambridge University Press. https://doi.org/10.1017/cbo9780511816819.004

Mule, R., \& Westberg, K. (2009). Mobile phone clickers in the classroom: Experiences from a large introductory marketing class. The World University's Forum, 2(5), 109-121.

National Center on Education and the Economy. (2006). Tough choices for tough times: The Report of the New Commission on the Skills of the American Work Force.

National Council for the Social Studies. (1994). Expectation of excellence: Curriculum standards for social studies. Washington.

Nielson, L., \& Webb, W. (2011). Teaching generation next-Using cell phones to enhance learning. San Francisco: Jossey-Bass.

Piaget, J. (1977). The role of action in the development of thinking. In W. F. Overton, \& J. M. Gallagher (Eds.), Advances in research and theory. New York: Plenum Press. https://doi.org/10.1007/978-1-4684-2547-5_2 
Raes, A., \& Schellens, T. (2012). Scaffolding information problem solving in web based collaboration inquiry learning. Computers and Education, 59, 82-94. https://doi.org/10.1016/j.compedu.2011.11.010

Reeve, J., \& Deci, E. L. (1999). Elements of the competitive situation that affect intrinsic motivation. Personality and Social Psychology Bulletin, 22(1), 24-33. https://doi.org/10.1177/0146167296221003

Roll, L., \& Holmes, N. G. (2012). Evaluating metacognitive scaffolding in guided invention activities. Instruction and Science. An Instructional Journal of the Learning Science, 40, 692-710. https://doi.org/10.1007/s11251-012-9208-7

Rothkopf, E. Z. (1966). Learning from written instructive materials: An exploration of the control of inspection. American Educational Research Journal, 3(4), 241-249. https://doi.org/10.3102/00028312003004241

Seol, S., Sharp, A., \& Kim, P. (2012). Stanford Mobile Inquiry based Learning Environment (SMILE) using mobile phones to promote student inquires in the elementary classroom.

Sharpe, T. (2006). Impacting' scaffolding: Identifying discourse and multimodel strategies that support learning. Language and Education, 20(3), 211-231. https://doi.org/10.1080/09500780608668724

Shih, J. L., Chuang, C. W., \& Hwang, G. J. (2010). An inquiry-based mobile learning approach to enhancing social science learning effectiveness. Educational Technology Society, 13(4), 50-62.

Spronken, S., \& Rachel, B. J. (2008). Where night sand dunes lie Mars' engaging students through inquiry based learning in geography. Journal of Geography in Higher Education, 32, 71-86. https://doi.org/10.1080/03098260701731520

Strijbose, J. W., \& Sluijsmans, D. (2010). Unravelling peer assessment methodological, functional, and

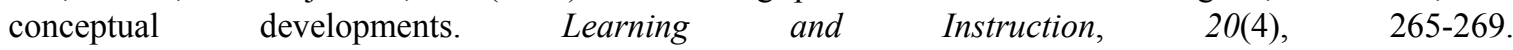
https://doi.org/10.1016/j.learninstruc.2009.08.002

Swan, K., van'tHooft, M., Kratcoski, A., \& Unger, D. (2005). Uses and effects of mobile computing devices in K-8 classrooms. Journal of Research on Technology in Education, 38(1), 90-112. https://doi.org/10.1080/15391523.2005.10782451

Williams, E. (1992). Student attitudes towards approaches to learning and assessment. Assessment and Evaluation in Higher Education, 7(1), 45-58. https://doi.org/10.1080/0260293920170105

Wilson, R. C. (1986). Improving faculty teaching: Effective use of student evaluations and consultants. The Journal of Higher Education, 57(2), 196-211. https://doi.org/10.2307/1981481

Yu, F. Y. (2000). Scaffolding student-generated questions: Design and development of a customizable online learning system. Computers in Human Behavior, 42(5), 1129-1138.

Yu, F. Y. (2005). Promoting metacognitive strategy development through online question-generation instructional approach. Proceeding of International Conference on Computers in Education, 2005, 564-571.

Yu, F. Y., Liu, Y. H., \& Chan, T. W. (2005). A web based learning system for question-posing and peer assessment. Innovations in Education and Teaching International, 42(4), 337-348. https://doi.org/10.1080/14703290500062557

\section{Copyrights}

Copyright for this article is retained by the author(s), with first publication rights granted to the journal.

This is an open-access article distributed under the terms and conditions of the Creative Commons Attribution license (http://creativecommons.org/licenses/by/4.0/). 